\title{
Analysis and visualization of the glass eel behavior (Anguilla anguilla) in the Adour estuary and estimate of its upstream migration speed
}

\author{
Patrick Prouzet ${ }^{1, a}$ Marc Odunlami $^{2}$, Elise Duquesne ${ }^{3}$ and Ahmed Boussouar ${ }^{4}$ \\ 1 Ifremer, Laboratoire Ressources halieutiques Aquitaine, 1 allée du Parc Montaury, 64600 Anglet, France \\ 2 Université de Pau et des Pays de l'Adour-CNRS, Laboratoire de Mathématiques et de leurs Applications, UMR 5142, BP 1155, \\ 64013 Pau Cedex, France \\ 3 Institut des Milieux aquatiques, 1 rue de Donzac, BP 106, 64101 Bayonne Cedex, France \\ 4 Association pour le Développement de l'Enseignement et des Recherches auprès des Universités, des Centres de Recherche et des Entreprises \\ d'Aquitaine, BP 196, 33608 Pessac Cedex, France
}

Received 5 January 2009; Accepted 21 July 2009

\begin{abstract}
The studies carried out on the Adour estuary on the migration of glass eels lead to the characterisation of their swimming behavior. Individuals migrate passively with the flood tide current behind the dynamic tide front, and their movements into the water column are linked to the surrounding luminosity and water turbidity. A numerical model was built from observations gathered on glass eel densities during scientific surveys. It uses the outputs of a hydrodynamic model accounting for the variations in the river flow and tide coefficient. It allows the simulation of the displacement of a particle in the longitudinal axis of the estuary. The variation of the vertical movements through the water column takes into account the cloud cover, the moon phases, the alternation of days and nights and the water turbidity. The results allow displaying the migration speed of groups of glass eels entering the Adour estuary. These simulations are validated by the comparison with in situ observations and the outputs of the behavioral model make possible, on the one hand, to simulate the migration speed of glass eels according to hydrological data and, on the other hand, to define the environmental conditions that stop or slow down their displacement into the estuary.
\end{abstract}

Key words: Numerical modeling / Fish behavior / Migration / Estuary / Hydrodynamics / Exploitation rate / Glass eel / Anguilla anguilla / Atlantic Ocean

\begin{abstract}
Résumé - Les études développées sur l'Adour et concernant la migration des civelles en estuaire ont permis de préciser certaines caractéristiques de leur comportement de nage. Les individus se laissent porter par le courant de marée derrière le front de marée dynamique et se déplacent verticalement dans la colonne d'eau en fonction de la luminosité ambiante et de la turbidité de l'eau. Un modèle numérique a été construit à partir d'observations collectées sur les densités de civelles dans la colonne d'eau durant des campagnes scientifiques. Il utilise les sorties d'un modèle hydrodynamique prenant en compte les variations du débit et du coefficient de marée. Il permet ainsi de simuler les vitesses de déplacement d'une particule dans l'axe longitudinal. La variation des mouvements verticaux dans la colonne d'eau prend en compte la nébulosité, les phases lunaires ainsi que l'alternance des jours et des nuits et la turbidité de l'eau. Le résultat est une visualisation des vitesses de déplacement des groupes de civelles pénétrant dans l'estuaire de l'Adour. Ces simulations sont comparées aux observations tirées des séries de captures journalières observées sur deux pêcheries bien distinctes de l'estuaire. La confrontation permet de valider les sorties du modèle comportemental et de bien visualiser la vitesse de déplacement en fonction des données hydrologiques ainsi que les conditions environnementales qui bloquent ou freinent le déplacement des flux de civelles dans l'estuaire.
\end{abstract}

\section{Introduction}

The study of glass eel migration in the Adour River estuary (De Casamajor 1998; Bru 1998; Prouzet 2002, 2003)

\footnotetext{
${ }^{a}$ Corresponding author: Patrick.Prouzet@ifremer.fr
}

confirmed that the upstream migration is passive, using the propagation of the dynamic tide. The migration of glass eels into the estuary is not continuous, but in "waves" (De Casamajor et al. 2000). The entry into fresh water may be driven either by the sense of smell, which plays a role in the homing mechanism of migratory salmonids (Saglio 1994), the 
electric fields or a biological clock (McCleave and Kleckner 1982; Creutzberg 1961). The variation of salinity is also advanced by some authors as one possible attractive cue (Fontaine and Callamand 1941), but this theory has been questioned (Creutzberg 1961). During the main migration season, which in the Adour takes place generally from October to March, a reduction in the size and weight of glass eel caught is observed (De Casamajor et al. 2001; De Casamajor et al. 2000; Charlon and Blanc 1982). Generally, the mean size of individuals ranges between 68 and $76 \mathrm{~mm}$ (De Casamajor et al. 2003) for the southeastern part of the Bay of Biscay. Hydroclimatic conditions play a major role in the behavior of the fish. The tide coefficient and the river flow control the speed of upstream displacement through the estuary, whereas water turbidity and nocturnal luminosity have an effect on the position of individuals into the water column (De Casamajor et al. 1999).

The purpose of this work is to simulate the upstream movement of glass eels when they enter the lower part of the river, characterized by the displacement of the tide through the estuary, and to study the speed of glass-eel migration before the elver stage (i.e. before the settlement phase of individuals) and to test the hypothesis of a diurnal migration when the tide is rising. The numerical model takes into account different hydrodynamic parameters such as speed of the tidal current, river flow, water turbidity, cloud cover and moon phases. As the level of catches is the product of fish availability, fishing intensity and fish density, it was interesting to model the migratory behavior of glass eel through the lower part of the estuary in order to simulate the influence of hydroclimatic conditions on fish availability, and particularly on the accumulation of groups of individuals in the lower part of the estuary. This study specifies the link between the exploitation rate of the pushed scoop-net fishery and the hydrodynamic conditions, information required to estimate, from catch data, the daily or seasonally migrating glass eel biomass.

\section{Biological background}

\subsection{From the larva to the glass eel stage}

The biological cycle of the European eel (Anguilla anguilla) is complex, and its understanding still presents many grey areas. For example, the reproduction was never observed, and no eggs or spawners have been captured in the supposed spawning area (Nilo and Fortin 2001) located in the Sargasso Sea. Schmidt (1925, in Nilo and Fortin 2001) observed for Anguilla anguilla a peak of spawning in March, a result confirmed in 1979 (Tesch and Wegner 1990). It is indeed very likely that the reproduction is carried out at several hundred meters of depth, in the epipelagic zone (Kleckner et al. 1983). The smallest larvae are captured between 200 and 300-m depth (Schoth and Tesch 1984). According to Boëtius and Boëtius (1980) the fecundity of European eel ranges between 0.7 and 2.6 million eggs for individuals measuring between $630 \mathrm{~mm}$ and $790 \mathrm{~mm}$.

The larvae, called leptocephalae, are carried by the ocean currents in a passive way, but undertake active daily vertical migrations of several hundred meters according to a nychthemeral rhythm. In the vicinity of the continental slope, after an average life span of 1 to 4 years (Lecomte-Finiger and Yahyaoui 1989; Lecomte-Finiger 1992; Antunes and Tesch 1997; Tesh 2003), the larva is transformed into glass eel, the length of which reaches approximately $70 \mathrm{~mm}$, and stops feeding.

\subsection{Glass eel behavior during estuarine migration}

At sea, the glass eel is almost transparent. When the individuals arrive at the mouth of the estuary, the pigmentation stage is defined from a grid of pigmentation levels (Elie et al. 1982). The degree of pigmentation is controlled by the time spent in the estuary, the temperature and the salinity (Briand et al. 2004).

Several authors such as Creutzberg (1961), McCleave and Kleckner (1982), Sheldon and McCleave (1985) have studied the migratory behavior of glass eels in an estuary. With the flood tide, glass eels rise into the water column, moving upstream with the water. During the ebb tide, they maintain their position in the river by first coming close to the bottom and then burying themselves in the substrate. Creutzberg (1961) demonstrated in the laboratory that glass eels expressed a positive rheotaxis for ebb currents of $0.2 \mathrm{~m} \mathrm{~s}^{-1}$, and a negative one for ebb currents higher than $0.36 \mathrm{~m} \mathrm{~s}^{-1}$, swimming close to or burying into the bottom. This behavior is observed on sandy substrates, while hiding is preferred on gravel bottoms. These results are confirmed by the observations made of the Adour River regarding the presence or absence of fish in the water column in relation to current speed and direction. Glass eels have been found in the water column when the downstream current had a speed lower than $30 \mathrm{~cm} \mathrm{~s}^{-1}$ (Prouzet et al. 2003; Adam et al. 2008).

In average hydrological conditions, glass eels penetrate in low or medium density into the estuary following the rhythm of flood tides. Nothing indicates, at the moment, that they do it in any active way. On the contrary, the most recent observations of the accumulation of glass eels in the vicinity of the front of the dynamic tide lead to believe that they move rather passively in the estuary (Cantrelle 1984; Sheldon and McCleave 1985; Prouzet et al. 2003; Adam et al. 2008). Observations made during the INDICANG project ${ }^{1}$ (Adam et al. 2008) in the lower part of the Oria River estuary (Basque country), where a halocline exits, show a higher density of glass eels under the halocline. Further upstream, the glass eels disperse progressively in the water column as the halocline disappears.

During a river flood, in the maritime as well as fluvial part of the estuary, currents are essentially downstream, and glass eels concentrate close to the river banks, where currents are weaker, to avoid being carried back. Observations made during such an event on the Adour estuary fishery show some good catches with the hand sieve close to the banks, in areas where the fish find calm shallow waters. In these conditions, however, the hydrodynamic characteristics prevent also the eels from moving upstream and create a hydrodynamic lock chamber where different runs of glass eels accumulate. It is generally when the tide progresses again after the end of the flood that

\footnotetext{
1 http://www.ifremer.fr/indicang.fr/
} 


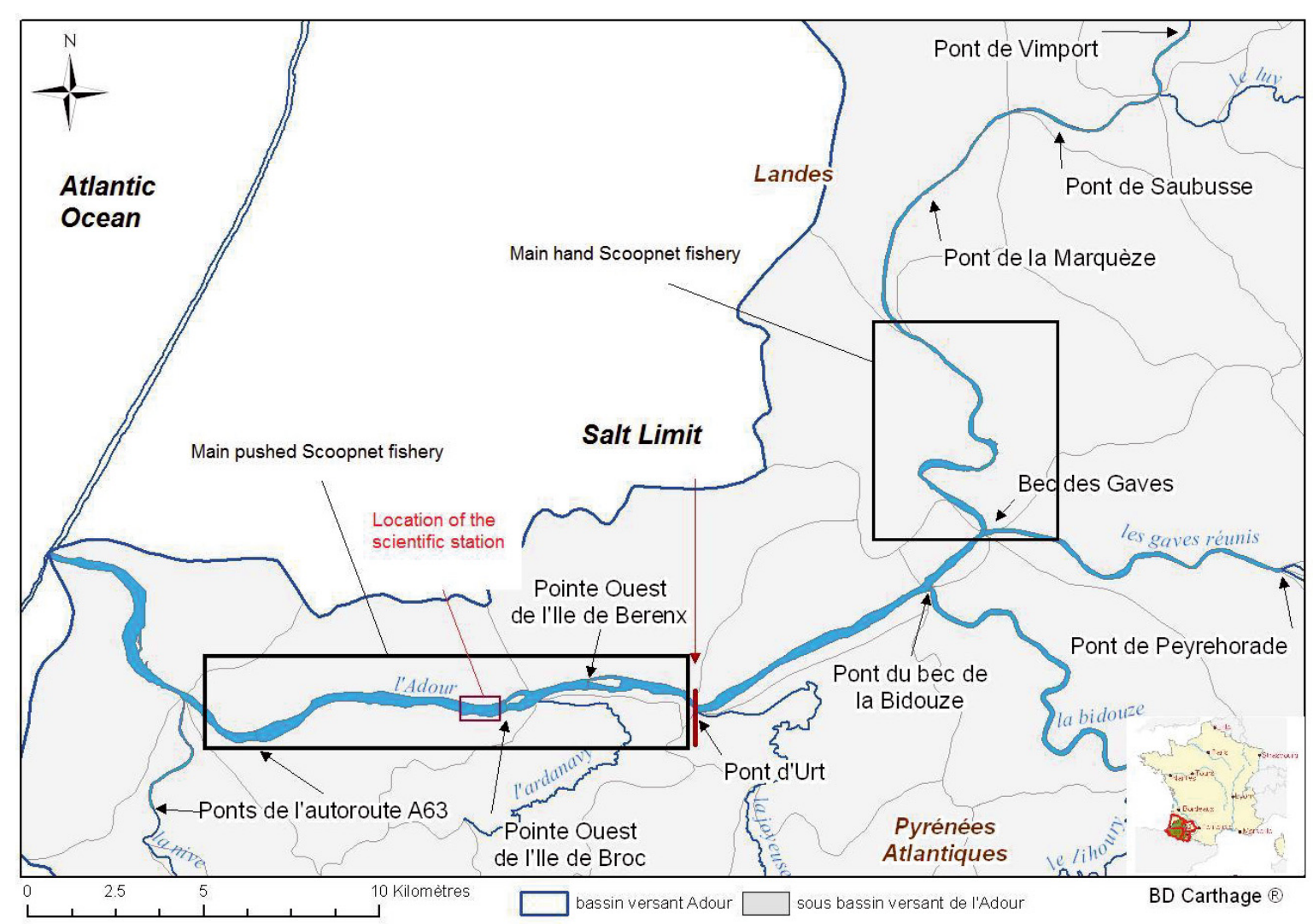

Fig. 1. Map of the Adour estuary and locations of the two main glass eels fisheries.

we can observe some peak catches in the estuary during the main migration period.

The vertical migratory behavior of glass eel was analyzed from densities observed at different depths (Prouzet et al. 2003). The position of individuals in the water column depends on environmental conditions and more particularly on lighting. The vertical location of glass eels is related mainly to turbidity and phase of lunar cycle (De Casamajor 1998; Bru 1998; De Casamajor et al. 1999). In turbid water, migrating individuals are found through the entire water column, whatever the phase of the lunar cycle. In clear water, they move close to the bottom, especially during full moon.

Nebulosity is a modulating factor of night luminosity, which can attenuate the penetration of lunar light, particularly during the first and last lunar quarters. The vertical movements in the water column are rather active and result from a lucifugous behavior. In artificial conditions, Bardonnet et al. (2005) showed the extreme sensitivity of glass eels to low level of luminosity $\left(10^{-11} \mathrm{~W} \mathrm{~cm}^{-2}\right)$. In highly turbid water (higher than 100 NTU, nephelometric unit), glass eels are found in the entire water column, whatever the night brightness (De Casamajor 1998; De Casamajor et al. 1999; Prouzet et al. 2002, 2003; Bardonnet et al. 2005). In clear water, except during new moon, glass eels are generally found close to the bottom, out of reach of pushed or hand-held scoop nets. This is the reason why in the area above the "Bec des Gaves" in the Adour River (see Fig. 1) the anchored scoop net is used when turbidity is low, especially at twilight during the rising tide. In the Adour, the level of water turbidity affects the catchability of the individuals when they migrate through the estuary and is a significant parameter to determine exploitation rate of glass eels in the pushed scoop-net fishery (Bouvet et al. 2006; Bru et al. 2006).

\section{Materials and methods}

\subsection{Study area}

The Adour flows into the Atlantic Ocean and joins the Bay of Biscay after a course of $312 \mathrm{~km}$ from the Pyrenees. Its principal tributaries are the Gave de Pau, the Gave d'Oloron and the Nive (Fig. 1). Its channelized mouth is located at $43^{\circ} 30$ North and $1^{\circ} 332$ West. At this place, on average, the width of the estuary does not exceed $150 \mathrm{~m}$ and the depth is of $12 \mathrm{~m}$.

The river flow at the mouth (mean 1949-1992) is $275 \mathrm{~m}^{3} \mathrm{~s}^{-1}$. The lowest water level is usually observed in August and September. On average, there are three river floods higher than $1000 \mathrm{~m}^{3} \mathrm{~s}^{-1}$ per year: two in winter (November/December and January/February) and one in spring (April/May, sometimes in June).

In the Bay of Biscay, the tide is semi-diurnal, with an average period of 12 hours and $25 \mathrm{~min}$. The dynamic tide can be felt up to $68 \mathrm{~km}$ from the mouth on the Adour and up to $40 \mathrm{~km}$ on the Gaves "réunis" (Snoussi 1988). Below the confluence with the Nive River (Fig. 1), the water column is stratified during the flood tide. Above this confluence, this stratification disappears. 


\subsection{Glass eel fisheries}

The glass eel fishery is a very valuable activity for marine fishers and is conducted mainly between the confluence with the Nive and $10 \mathrm{~km}$ from the confluence with the Gaves on the Adour (see Fig. 1). As with all French rivers, the level of catches has decreased significantly since the eighties, a period during which the reported landings in that estuary oscillated between 2 and 12 metric tons (Lissardy et al. 2004-2005). The boats used are generally smaller than $8 \mathrm{~m}$ in length. Two different fishing gears are used: the pushed scoop net and the hand scoop net, both with a square mesh size of $1-1.2 \mathrm{~mm}$. The hand scoop net is mainly used on the Adour above the confluence with the Gaves. The pushed scoop net is allowed exclusively below Urt, within the first $20 \mathrm{~km}$ from the mouth of the Adour (see Fig. 1).

Glass eels are caught during night, when the flood tide enters the estuary. The boats move against the tide current pushing two scoop nets of $1.5-\mathrm{m}$ diameter. A haul typically lasts 5 to $25 \mathrm{~min}$, and the catch is laid on a plastic grid of 5-mm mesh on top of a holding tank.

Each fisher enters in a logbook for each trip the catch weight and the fishing area. This data, stored in a central database at Ifremer, allow to determine the total catch per day or the mean catch per trip and their fluctuation during the fishing season.

Two locations were selected as reference fishing zones: (i) below Urt city, where the use of the pushed scoop net is permitted and (ii) the Adour above the confluence with the Gaves, where the hand scoop net is mainly ${ }^{2}$ used and the pushed scoop net is prohibited.

Our objective is to compare the catch fluctuations in the two fishing areas in order to detect the time lag between the significant peaks in each area (i.e. the time spent by the groups of glass eels between the two fishing areas) and to estimate an average migration speed to be compared with that given by the numerical simulation.

\subsection{Numerical modeling}

Pardo (2002) proposed a two-dimensional model describing, at time $t$, the instantaneous variation of glass eel density in an estuary. Contrary to other approaches based on describing a group of glass eel as separate individuals (Gómez-Mourelo 2005), this model considers glass eels at population level. Our goal is not to assess the differences between glass eels belonging to the same group, but to study the general behavior of a set of individuals. Our model is built from Pardo's and provides a mathematical translation of the glass eel behavior. It expresses the evolution of glass eel density in the estuary as a function of hydroclimatic factors. The governing equations of the model are detailed in the Appendix (online only supporting information). This model is only valid for the part of the estuary subject to the dynamic tide with no hydrological stratification (i.e. no strong halocline or thermocline).

\footnotetext{
${ }^{2}$ Another gear (the anchored scoop net) is allowed in the Adour above the confluence with the Gaves.
}

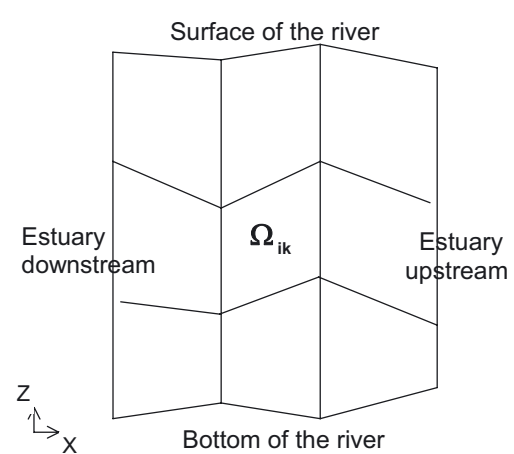

Fig. 2. Space discretization of the Adour estuary on two dimensional cells designed by $\Omega_{i k}$.

Table 1. Hydrodynamic conditions corresponding to the catch peaks recorded in the two fisheries during the 1999-2000 fishing season (4 situations).

\begin{tabular}{llllll}
\hline $\begin{array}{l}\text { Adour } \\
\text { River }\end{array}$ & $\begin{array}{l}\text { Date } \\
1999\end{array}$ & $\begin{array}{l}\text { Pushed } \\
\text { scoop-net } \\
\text { catches } \\
(\mathrm{kg})\end{array}$ & $\begin{array}{l}\text { Hand } \\
\text { scoop-net } \\
\text { catches } \\
(\mathrm{kg})\end{array}$ & $\begin{array}{l}\text { Tide } \\
\text { Coeff. }\end{array}$ & $\begin{array}{l}\text { River } \\
\text { flow } \\
\left(\mathrm{m}^{3} \mathrm{~s}^{-1}\right)\end{array}$ \\
\hline 1 & Nov. 9 & 92 & 69 & 85 & 140 \\
& Nov. 10 & 73 & 92 & 80 & 145 \\
& Nov. 11 & 51 & 138 & 74 & 138 \\
& Nov. 12 & 36 & 158 & 66 & 129 \\
\hline 2 & Dec. 8 & 205 & 88 & 79 & 139 \\
& Dec. 9 & 181 & 117 & 78 & 142 \\
& Dec. 10 & 137 & 216 & 75 & 322 \\
\hline 3 & Dec. 13 & 184 & 202 & 58 & 491 \\
& Dec. 14 & 204 & 185 & 51 & 424 \\
\hline 4 & Dec. 28 & 114 & 173 & 65 & 859 \\
& Dec. 29 & 132 & 126 & 54 & 1070 \\
\hline
\end{tabular}

Let $C=C(t, x, z)$ be the glass eel density at time $t$ and at a given point of the estuary with coordinates $(x, z)$. The longitudinal variable, $x$, is zero at the river mouth and increases in the upstream direction of the estuary. The vertical variable, $z$, increases from the bottom (the depth of which is variable) to the surface of the river, and its zero corresponds to the zero water level of the marine charts.

In this model, the river width is not taken into account, and the density observed at a point of coordinates $(x, z)$ is considered valid for all points with similar coordinates, i.e. for the whole cross section of the river. The model requires space and time discretization. Using the finite volume method, we first divide the estuary into quadrangular cells $\Omega_{i k}$ in order to approximate a changing $C$ by a constant $C_{i k}$ on each of those cells (Fig. 2). Then, we integrate $C_{i k}$ over time to obtain an instantaneous value for glass eel density in each cell.

The glass eel behavioral model has been implemented using $\mathrm{C}++$ finite volume routines developed in the LibMesh library (Kirk et al. 2006). Users need to provide information about estuary state (bathymetry, river flow, glass eel density) at the beginning of the simulation. Another important part of the software is a one-dimensional hydrodynamic module calculating the current speeds and the heights of water in the river (Prouzet et al. 2002) which are assumed to depend only on the longitudinal variable $x$. The hydrodynamic model is based 


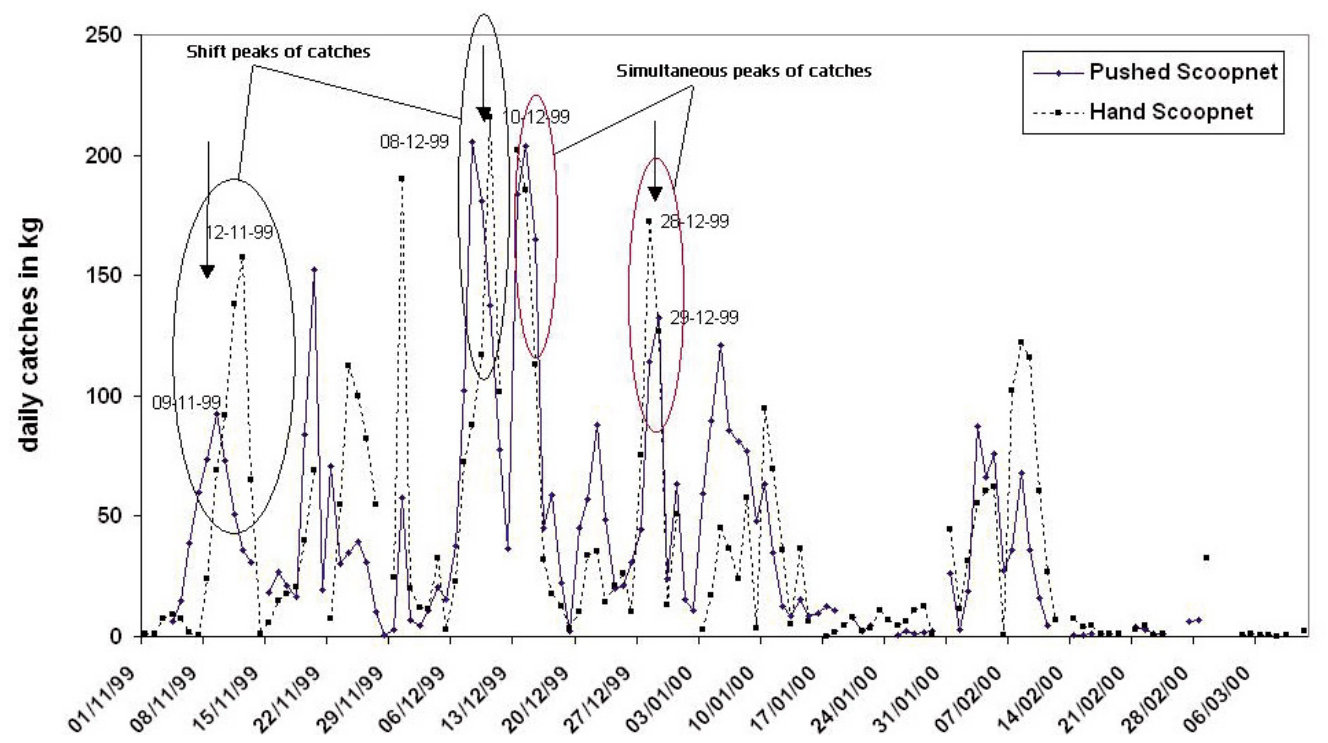

Fig. 3. Daily catches in the two fisheries during the 1999-2000 fishing season.

on the Saint-Venant equations (Graf 1998). Besides, in the behavioral model, the possibility of a diurnal migration is considered. Thus, if the flood tide occurs in broad daylight, the code simulates two options: (i) glass eels migrate very close to the bottom or (ii) remain hidden in the sediment. The software takes into account turbidity, night nebulosity and lunar phases, which play a role in the vertical dispersion through the water column. It also considers glass eel's behavior by simulating a passive longitudinal migration and active vertical movements. Finally, it is possible to inject at the mouth of the estuary a given density of glass eels at specific times. Using Scilab software (Pinçon 2004; Mottelet 2006), the results are represented as clouds of glass eel densities.

\section{Results}

\subsection{Catch variations (1990-2000 fishing season)}

The 1999-2000 fishing season (from November 1999 to March 2000), the most productive season of the last ten years, is taken as an example. In Figure 3, the timing of the significant catch peaks in the pushed scoop net and hand scoop net fisheries, located $20 \mathrm{~km}$ apart (Fig. 1), can be compared. The peaks observed in the lower fishery (below Urt city) and the upper one (above the "Bec du Gave") may either be separated by a time lag of two to three days or occur simultaneously.

These two patterns are linked to two different hydrodynamic situations (Table 1). In the first instance (situations 1 and 2: Fig. 3 and Table 1), the river flow is low or medium and is associated with high and moderate tide coefficients. Under these circumstances, the propagation of the front of the dynamic tide through the estuary is fast (Fig. 4). In the second instance (situations 3 and 4), the tide does not progress far from the mouth. In situation 3, the tide coefficient is too low (less than $60)$ to allow an important displacement of the dynamic tide. In situation 4 , the river flow, higher than $850 \mathrm{~m}^{3} \mathrm{~s}^{-1}$ corresponds to a flood, preventing the tide to propagate through the estuary.

On 28 December 1999, the hydrodynamic model used in the glass eel behavioral model shows that, even during the

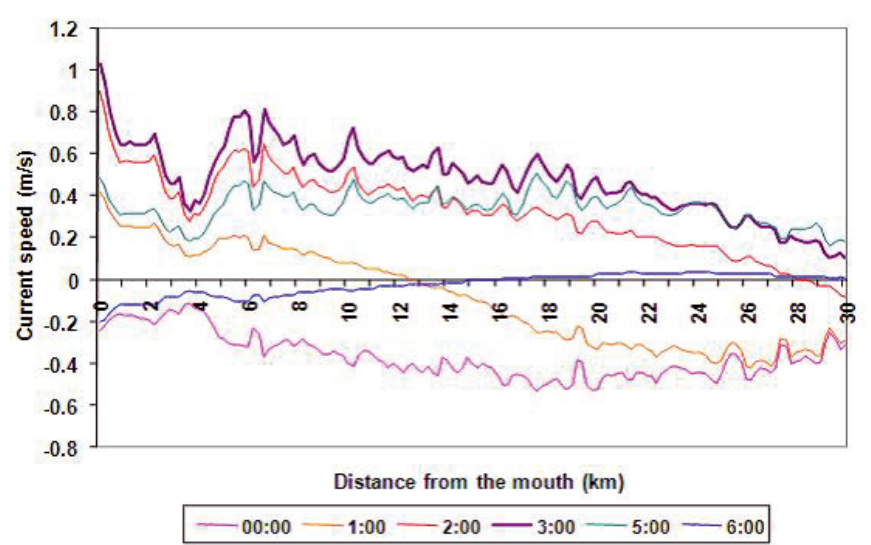

Fig. 4. Simulation of the water current speeds: 9 November 2009 from 24:00 to 06:00.

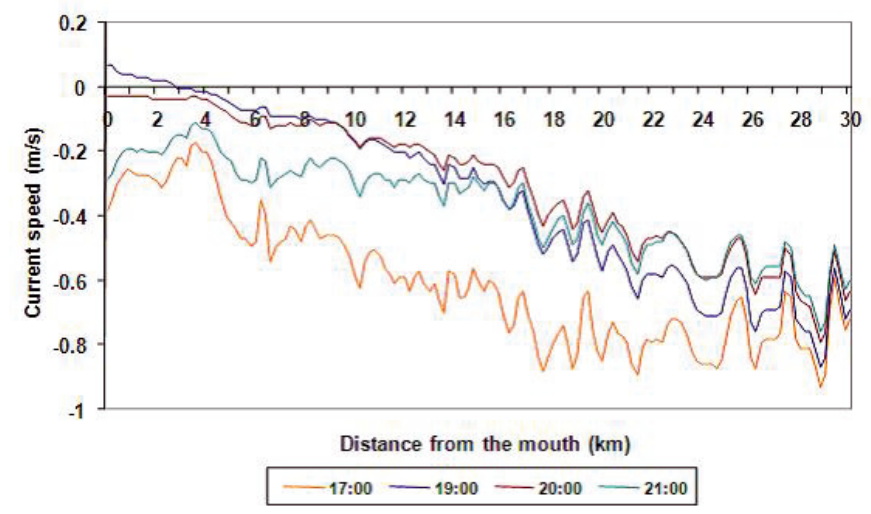

Fig. 5. Simulation of the water current speeds: 28 December 2009 from 17:00 to 21:00.

rising tide, between 15:00 and 22:00, the current remains directed towards the mouth in a large part of the estuary (Fig. 5). We observe the same phenomenon on 29 December, with a mean current speed along the estuary estimated with the hydrodynamic model at $-0.43 \mathrm{~m} \mathrm{~s}^{-1}$. These hydrological 

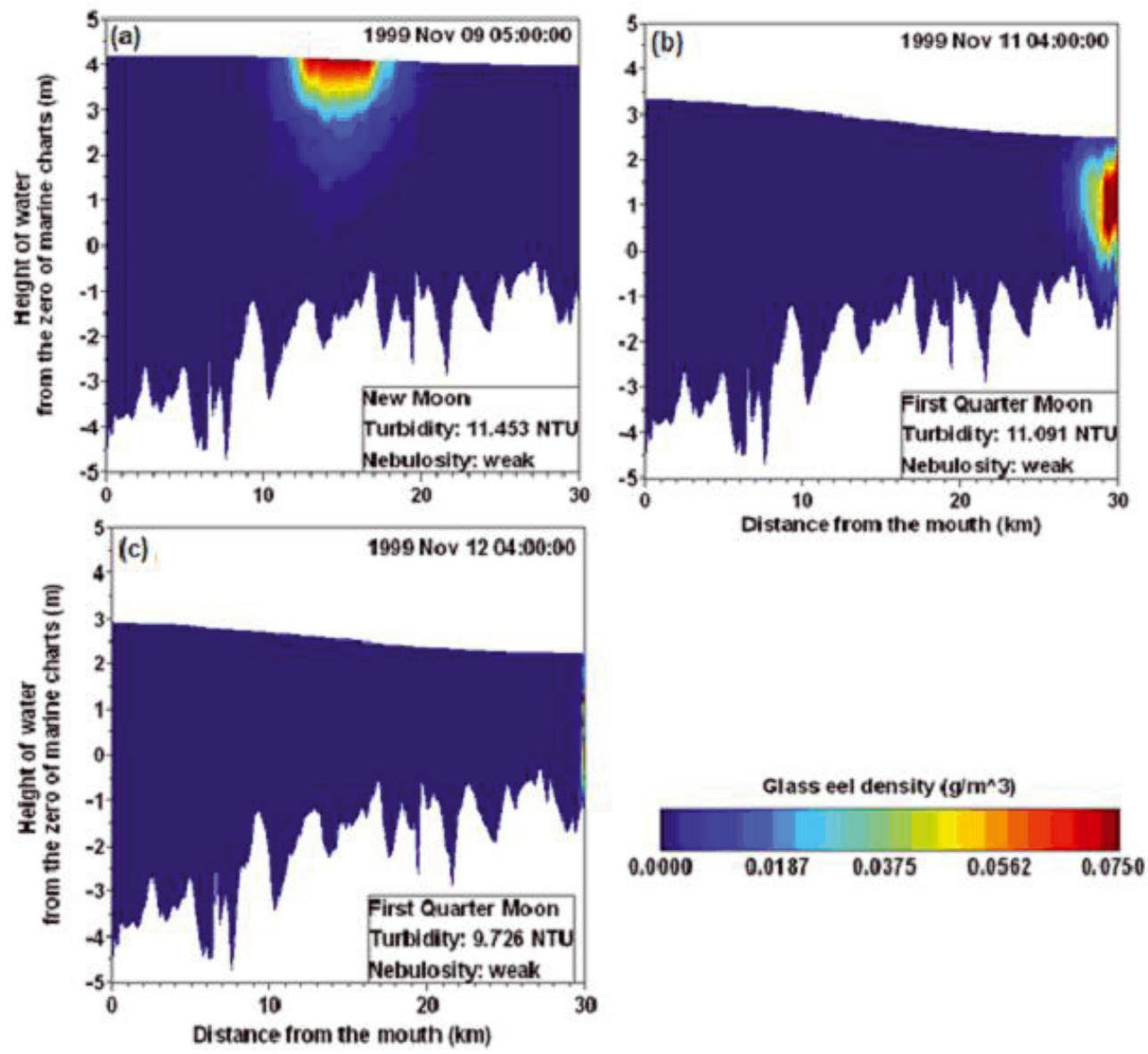

Fig. 6. Simulated migration of one run assuming diurnal migration (see text).
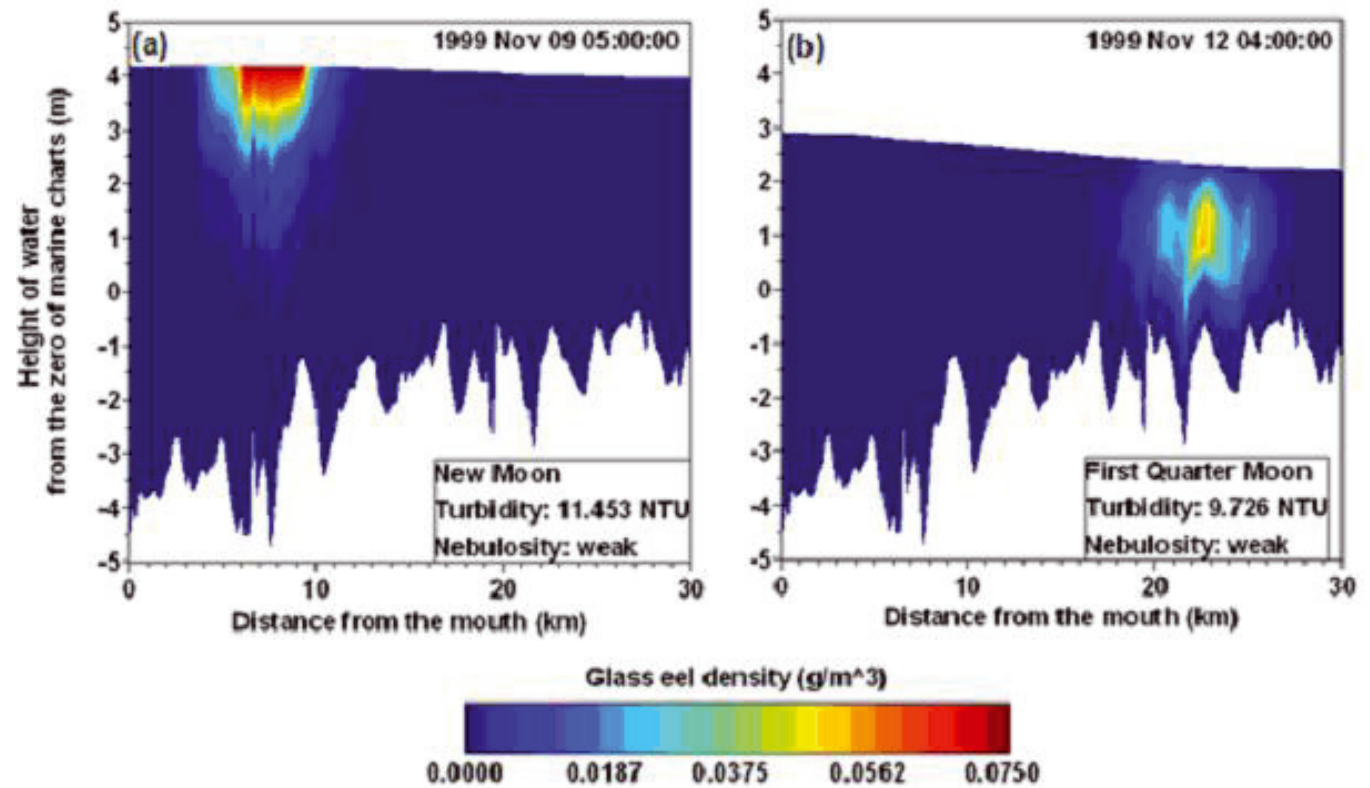

Fig. 7. Simulated migration of one run assuming diurnal burying behavior (see text). 
conditions prevent glass eels from moving upstream and favor their concentration close to the banks in some locations where the fish is available for the fishery.

\subsection{Effects of hydrodynamic conditions}

In the following sections, the model will be used to simulate the displacement of groups of glass eels according to hydrodynamic conditions.

\subsubsection{Displacement speed with the dynamic tide}

It is important to estimate the displacement speed through the estuary during the propagation of the dynamic tide. The correspondence of the significant catch peaks in two consecutive fisheries is used to calculate the average speed of groups of glass eels migrating upstream in the estuary. We consider as an example situation 1 (Table 1), showing a peak in the catches of the pushed scoop-net fishery on 9 November 1999, followed by a peak in the catches of the hand-held scoop-net fishery on the $12^{\text {th }}$ of November (Fig. 3). During this period, the hydrodynamic conditions are favorable to the propagation of runs of glass eels upstream in the estuary.

The question is: "Is the catch peak observed upstream in the fluvial zone, on 12 November, taken from the same glass eel run that produced a peak downstream into the maritime zone on 9 November?" Knowing that there were no floods during that period (Table 1), we reproduce the propagation of a glass eel run in the estuary between 9 and 12 November using the behavioral model previously presented.

If we "inject" a glass eel density of $0.5 \mathrm{~g} \mathrm{~m}^{-3}$ at the mouth of the estuary on 8 November during the diurnal flood tide we obtain the coincidence of the arrival of the run on 9 November in the maritime zone of the estuary, between 12 and $20 \mathrm{~km}$ from the sea (Fig. 6a), with a peak of catches in the lower fishery. If the run is forced to migrate remaining close to the bottom during the diurnal rising tide, it reaches the confluence with the Gaves, located $30 \mathrm{~km}$ from the mouth of the Adour on 11 November (Fig. 6b). Under these conditions, the run arrives in the upper fishery above the confluence with the Gaves on 12 November at 04:00 (Fig. 6c). On Figure 6c, the run has reached the extreme right-hand side of the picture and is thus hardly visible.

If, on the contrary, glass eels are forced to hide close to the river bed or to bury during diurnal flood tides, the speed of their upstream migration is inevitably slower. On 9 November, at 05:00, the run is still only between 4 and $11 \mathrm{~km}$ from the mouth (Fig. 7a). On 12 November, at 04:00, the run is located between 20 and $26 \mathrm{~km}$ from the mouth and has not yet reached the upper river fishery zone (Fig. 7b).

The second simulation is clearly not in accordance with the observed peaks of captures in the lower and upper fisheries observed, respectively, on 9 and 12 November 1999. These simulations, therefore, support the hypothesis of the existence of a migration of glass eels in the Adour estuary during the diurnal flood tides. Hence, it can be assumed that, when the hydrodynamic conditions allow the progression of the dynamic tide into the estuary, the average migration speed is close to that of the rising tide. In the above example, the estimated average speed of the tidal current ranged between 0.3 and $0.46 \mathrm{~m} \mathrm{~s}^{-1}$ during the 8-12 November simulation period. During that period, the glass eels covered about $40 \mathrm{~km}$ and the run that provided the peak of catches in the pushed scoop-net fishery (Fig. 3, situation 1) in the lower part of the estuary becomes available for the hand scoop-net fishery above the "Bec des Gaves", after five flood tides, i.e. after 2 or 3 days.

\subsubsection{Migration during a flood period}

The peaks of catches obtained on 13 and 28 December 1999 in the lower (pushed scoop-net) fishery happened simultaneously in the upper (hand scoop-net) fishery as shown in Figure 3 and Table 1 (situations 3 and 4). This situation may be reproduced by using the glass eel behavioral model in the hydrodynamic conditions prevailing during situation 4, assuming also that glass eels can migrate during the diurnal flood tide.

In the simulation, a glass eel density of $0.5 \mathrm{~g} \mathrm{~m}^{-3}$ is "injected" at the mouth of the estuary during three successive flood tides: on 27 December, at 04:00 and 16:00, and on 28 December at 04:00. On 27 December at 05:00 (Fig. 8a), the first glass eel run is located $2 \mathrm{~km}$ inside the mouth. At 17:00, the same day, the second group appears in the estuary, while the first group has migrated on the bottom during the day (Fig. 8b). On 28 December at 06:00, the third run is visible (Fig. 8c). This last group migrates faster than the previous ones and almost catches up with the second group at 20:00 the same day (Fig. 8d). At that time of the day, the current flows always outwards, except near the river mouth, where its direction is reversed, facilitating inward propagation (Fig. 5, top left angle). But 24 hours later, on 29 December, the three glass eel groups have not moved any further upstream (Fig. 8e), apparently due to totally unfavorable hydrodynamic conditions, and remain concentrated in the lower part of the estuary at about $12 \mathrm{~km}$ from the mouth.

This simulation indicates that the simultaneous peaks of catches observed in the two fishing zones $30 \mathrm{~km}$ apart on 28 and 29 December 1999 are likely to come from different runs of glass eels. It also suggests, however, that high densities of glass eels in the lower part of the estuary might indicate a retention and accumulation of successive runs by hydrodynamic features and not an exceptional recruitment of glass eels in the estuary. This may explain why changes in glass eel abundance in the estuary are not always correlated with the fluctuation in abundance of glass eels in the sea.

\section{Discussion}

\subsection{Estuarine migration speed}

The behavioral simulations made in this study are consistent with the hypothesis of an upstream migration close to the bottom during daytime, when the tide is rising into the estuary, even in clear water ${ }^{3}$. The average speed and the time necessary

\footnotetext{
3 Observations of catches close to the surface during the day on the Gironde estuary when the water is very turbid are usual on that estuary, characterized by a muddy bay.
} 

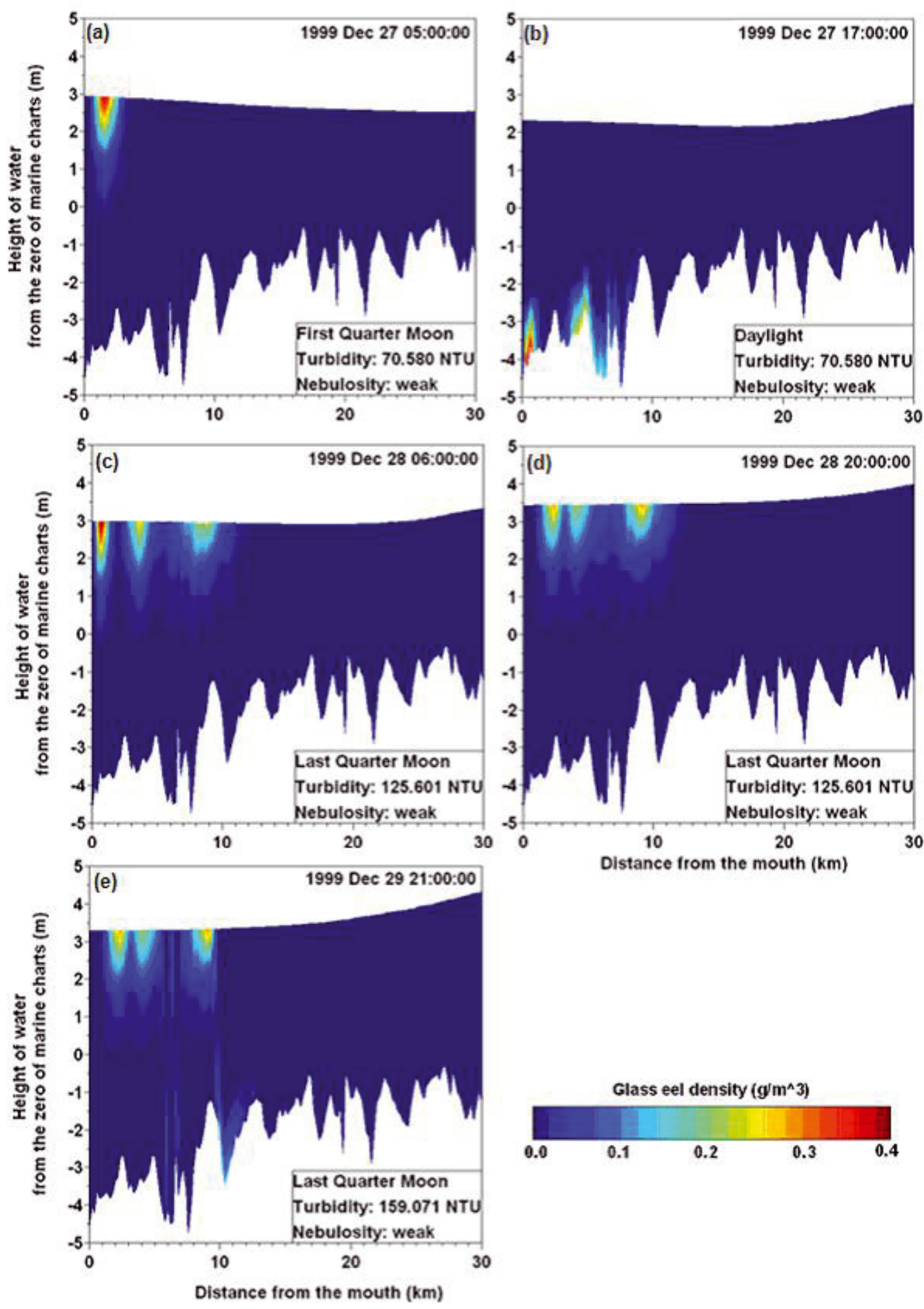

Fig. 8. Simulated migration of three runs during a river flood period (see text).

to cross the estuary are, of course, dependent on hydroclimatic conditions. In average hydrological conditions during the migration season (October to March), the migration speed may be equal to the displacement of the tide (roughly $0.4 \mathrm{~m} \mathrm{~s}^{-1}$ ), and the time necessary to travel around $10 \mathrm{~km}$ of estuary is about one day (or two rising tides ${ }^{4}$ ).

${ }^{4}$ Of 4 hours each in the medium part of the estuary.
McCleave and Kleckner (1982) estimated that glass eels could go up the estuary at a speed of 0.8 to $4.2 \mathrm{~km}$ per night according to the strength of the tide. Creutzberg (1961) in Holland, on the Wadden Sea, showed that glass eels continue their migration during the day. The catches of individuals were important during the flood tide in broad daylight at depths around $8 \mathrm{~m}$ (for a bathymetry ranging from 10 to $20 \mathrm{~m}$ ) and no or few eels were captured on the surface. 


\subsection{Improvement of the numerical modeling}

The simulation of migration through the estuary gave an estimate of the average migration speed in relation to hydroclimatic conditions. This kind of model is very informative to determine how many runs of glass eels are available to the pushed scoop-net fishery during a given flood tide in a certain area of the estuary. It was used in the Dordogne catchments to estimate the rate of exploitation of the glass eel fishery in the upper part of the estuary, where several groups of glass eels are brought in by different tide phases (Susperregui et al. 2007).

However, improved knowledge is still needed regarding the mean position of glass eels into the water column in relation to the absorption of light with depth, night brightness and water turbidity through direct observation as well as modelbased estimates (Prouzet et al. 2003). This might be undertaken in the framework of the coming "Eeliad" project ${ }^{5}$.

\section{Supporting Information}

Appendix: Glass eel behavioral model (after Pardo 2002, $\mathrm{PhD}$ thesis, Pau-Adour University). Supporting information is only available in electronic form at http://dx.doi.org/10.1051/ alr/2009041.s001.

\section{References}

Adam G., Feunteun E., Prouzet P., C. Rigaud, 2008, L'anguille européenne - Indicateurs d'abondance et de colonisation. Editions Quae, Versailles.

Antunes C., Tesch F.-W., 1997, A critical consideration of the metamorphosis zone when identifying daily rings in otoliths of European eel, Anguilla anguilla (L). Ecol. Freshw. Fish 6, 102107.

Bardonnet A., Bolliet V., Belon V., 2005, Recruitment abundance estimation. Role of glass eels (Anguilla anguilla) response to light. J. Exp. Mar. Biol. Ecol. 321, 181-190.

Boëtius I., Boëtius J., 1980, Experimental maturation of female silver eels, Anguilla anguilla. Estimates of fecundity and energy reserves for migration and spawning. Dana 1, 1-28.

Bouvet J.-C., Prouzet P., Bru N., 2006, Quantification de la biomasse saisonnière de civelles (Anguilla anguilla) dans l'estuaire de l'Adour et estimation du taux d'exploitation saisonnier de la pêche professionnelle de 1998 à 2005. Rapport Ifremer - projet Indicang http://www.ifremer.fr/indicang/sites-thematiques/ pdf/flux-saison.pdf.

Briand C., Fatin D., Lambert P., 2004, Effets de la température et de la salinité sur le développement de la pigmentation des civelles (Anguilla anguilla). Cybium 28, 247-254.

Bru N., 1998, Étude de quelques méthodes d'estimation non paramétriques de courbes. Application à l'évaluation de flux de civelles d'anguille. Thèse Univ. Pau, Math. Appli.

Bru N., Bouvet J.-C., Prouzet P., 2006, Quantification par une méthode analytique de la biomasse saisonnière de civelles (Anguilla anguilla) dans l'estuaire de l'Adour et estimation du taux d'exploitation saisonnier de la pêche professionnelle de 1998 à 2005. Rapport Ifremer - projet Indicang http://www.ifremer.fr/ indicang/sites-thematiques/pdf/estim-civelle-1998-2005.pdf.

5 “Eeliad" project : http://www.eeliad.com/index.html
Cantrelle I., 1984, Le marquage par coloration appliqué à l'étude des migrations de civelles (Anguilla anguilla). Cybium 8, 69-78.

Charlon N., Blanc J.M., 1982, Étude des civelles d'Anguilla anguilla dans la région du bassin de l'Adour. 1. Caractéristiques biométriques de longueur et de poids en fonction de la pigmentation. Arch. Hydrobiol. 93, 238-255.

Creutzberg F., 1961, On the orientation of migrating elvers (Anguilla vulgaris Turt.) in a tidal area, Neth. J. Sea Res. 1, 257-338.

De Casamajor M.-N., 1998, Comportement migratoire de la civelle d'anguille (Anguilla anguilla L.) dans l'estuaire de l'Adour en fonction de la variabilité des conditions environnementales. Thèse dr, Univ. Pau.

De Casamajor M.-N., Bru N., Prouzet P., 1999, Influence de la luminosité nocturne et de la turbidité sur le comportement vertical de migration de la civelle d'anguille (Anguilla anguilla $\mathrm{L}$.) dans l'estuaire de l'Adour. Bull. Fr. Pêche Piscic. 355, 327-347.

De Casamajor M.-N., Prouzet P., Lazure P., 2000, Identification des flux de civelles (Anguilla anguilla) à partir des relations d'allométrie en fonction des conditions hydrodynamiques de l'estuaire de l'Adour. Aquat. Living Resour. 13, 411-420.

De Casamajor M.-N., Lecomte-Finiger R., Prouzet P., 2001, Détermination de l'état d'amaigrissement des civelles (Anguilla anguilla) en migration en zones côtière et estuarienne. C.R. Acad. Sci. Paris Sér. III 324, 345-353.

De Casamajor M.-N., Lecomte-Finiger R., Prouzet P., 2003, Caractéristiques biologiques des civelles (Anguilla anguilla) lors de la transition en estuaire. Bull. Fr. Pêche Piscic. 368, 109-124.

Elie P., Lecomte-Finiger R., Cantrelle I., Charlon N., 1982, Définition des limites des différents stades pigmentaires durant la phase civelle d'anguille Anguilla sp. (poisson téléostéen anguilliforme). Vie Milieu 32, 149-157.

Fontaine M., Callamand O., 1941, Sur l'hydrotropisme des civelles. Bull. Inst. Océanogr. 811, 1-6.

Gómez-Mourelo P., 2005, A model for the upstream motion of elvers in the Adour River. C. R. Biologies 328, 367-378.

Graf W.H., 1998, Fluvial hydraulics: Flow and transport processes in channels of simple geometry. John Wiley.

Guéguen J., Prouzet P., 1994, Le saumon atlantique. Editions Ifremer.

Kirk B., Peterson J.W., Stogner R.H., Carey G.F., 2006, libMesh: A $\mathrm{C}++$ Library for parallel adaptive mesh refinement/coarsening simulations. Engin. Comput. 22, 237-254. http://cfdlab.ae.utexas. edu/ benkirk/libmesh-ewc-preprint.pdf.

Kleckner R.C., McCleave J.D., Wippelhauser G.S., 1983, Spawning of American eel, Anguilla rostrata, relative to thermal fronts in the Sargasso Sea. Environ. Biol. Fishes 9, 289-293.

Lecomte-Finiger R., Yahyaoui A., 1989, La microstructure de l'otolithe au service de la connaissance du développement larvaire de l'anguille européenne (Anguilla anguilla). C.R. Acad. Sci. Paris, Sér. III 308, 1-7.

Lecomte-Finiger R., 1992, Growth history and age at recruitment of European eels (Anguilla anguilla) as revealed by otolith microstructure, Mar. Biol. 144, 205-210.

Lissardy M., De Casamajor M.-N., Sanchez F., Morandeau G., Cuende F.-X., 2004-2005, Caractérisation et abondance des captures professionnelles estuariennes dans le bassin de l'Adour en 2003-2004. Rapport Ifremer-CERECA.

McCleave J.D., Klechner R.C., 1982, Selective tidal stream transport in the estuarine migration of glass eels of the American eel (Anguilla rostrata). J. Cons. Int. Explor. Mer 40, 262-271. 
Mottelet S., 2006, Plotlib, a "Matlab-like" plotting library for Scilab, on line at http://www.ema.utc.fr/ mottelet/myplot.html.

Nilo P., Fortin R., 2001, Synthèse des connaissances et établissement d'une programmation de recherche sur l'anguille d'Amérique (Anguilla rostrata). Université du Québec à Montréal, Département de Sciences Biologiques pour la Société de la Faune et des Parcs du Québec, Direction de la Recherche sur la Faune, Québec.

Pardo O., 2002, Contribution à l'étude et à la modélisation d'un modèle de convection-diffusion dégénéré : application à l'étude du comportement migratoire des civelles dans l'estuaire de l'Adour, $\mathrm{PhD}$ Pau-Adour Univ. on line at http://tel.archives-ouvertes.fr/ docs/00/04/51/42/PDF/tel-00002291.pdf.

Pinçon B., 2004, Une introduction à Scilab., on line at http://www. iecn.u-nancy.fr/ $\sim$ pincon/scilab/docA4.pdf.

Prouzet P. (coord), 2002, Historique des captures de civelles, intensité actuelle de leur exploitation, variation de leur capturabilité par la pêche professionnelle maritime et indice de colonisation sur le bassin versant de l'Adour. Rapport final, contrat EC/DG FISH (DGXIV) $\mathrm{N}^{\circ}$ 99/023.

Prouzet P. (coord), 2003, Étude sur la civelle (Anguilla anguilla) dans l'estuaire de l'Adour: Pêche, biologie, comportement, modélisations hydrodynamique et comportementale, estimations des flux de civelles en estuaire. Rapport Institution Adour-Ifremer-Univ. Pau-Adour.
Saglio Ph., 1994, Le retour aux sites de frai ou «homing »: les mécanismes chimiosensoriels. In Guéguen J, Prouzet P. (Eds.) Le saumon atlantique. Editions Ifremer, pp. 87-100.

Schoth M., Tesch F.-W., 1982, Spatial distribution of 0-group eel larvae (Anguilla sp.) in the Sargasso Sea. Helgol. Meeresunters 35, 309-320.

Sheldon M.R., McCleave J.D., 1985, Abundance of glass eels of the American eel, Anguilla rostrata, in mid-channel and near shore during estuarine migration. Nat. Can. 112, 425-430.

Snoussi M., 1988, Nature, estimation et comparaison des flux de matières issus des bassins versants de l'Adour (France) du Sebou, de l'Oum-Er-Rbia et du Souss (Maroc). Impact du climat sur les apports fluviatiles à l'océan. Mém. Inst. Géol. Bassin d'Aquitaine, Bordeaux 22.

Susperregui N., 2007, Rapport final Indicang : caractérisation de la pêcherie professionnelle de civelles sur l'Isle, Bassin versant Gironde-Garonne-Dordogne. http://www.ifremer.fr/indicang/ boite-bassins-versants/pdf/rapport-final-pecherie-bv-gironde. pdf.

Tesch F.-W., Wegner G., 1990, The distribution of small larvae of Anguilla sp. related to hydrographic conditions in 1981 between Bermuda and Puerto Rico. Int. Rev. Ges. Hydrobiol. 6, 845-858.

Tesch F.-W., 2003, The eel (5th Edition). J.-E. Thorpe (Ed.), Blackwell Publishing. 